\title{
A STUDY ON EFFECTS OF SILICA FUME ON MECHANICAL PROPERTIES OF LIGHT WEIGHT COCONUT SHELL CONCRETE
}

\author{
Shaik.Aliimran Tippu', Vr.Prasanth Kumar ${ }^{2}$ \\ ${ }^{1}$ Post Graduate Student, SRM University, Kattankulathur, Chennai \\ ${ }^{2}$ Faculty, SRM University, Kattankulathur, Chennai
}

\begin{abstract}
The rising value of construction materials in many countries needs to research and implement of different alternative materials in civil engineering construction. In India, concerning 890 million tonnes of solid wastes are being generated annually as byproducts throughout industrial and agricultural. The Above wastes can be used as aggregate in concrete for the production of light weight concrete. Amid this study, coconut shell is utilized as light-weight mix in concrete. The undertaking paper goes for examining split tensile strength and compressive strength characteristics with complete replacement of coarse combination with coconut shell to supply light-weight concrete and to exchange cement by exploitation silica fume as admixtures with completely different percentages $(0 \%, 10 \%, 15 \%, 20 \%, 25 \%$ and $30 \%)$ to urge smart strength like standard concrete. Concrete 63 cubes and 63 cylinders are casted with mix proportion (1:1.47:0.65) and their mechanical properties are determined and compared with standard concrete. The employment of coconut shells as for standard aggregates ought to be inspired as an environmental protection and construction value reduction measure.
\end{abstract}

Keywords: Coconut shell (CS), light weight concrete (LWC), Light Weight Aggregate (LWA), Surface Saturated Dry (SSD), Normal Weight Concrete (NWC), NC Normal Concrete

\section{INTRODUCTION}

Light weight concrete has less self weight of concrete .Density of LWC concrete varies from $330 \mathrm{~kg} / \mathrm{m}^{3}$ to 1850 $\mathrm{kg} / \mathrm{m}^{3}$.It has many advantage when compared to normal concrete, less dead load ,fasten the construction progress of building, less handling cost of materials, flexible in design adaptable in weak soil. Another main characteristic of light weight concrete is low thermal conductivity which improves decreasing density. Light weight concrete has become more popular in recent years owning to tremendous advantages it offers over conventional concrete. Many research attempts have been done on light weight concrete and many new technologies have also helped much in use lightweight concrete.

The main characteristic of this light-weight mixture is its high consistency which ends in a very low relative density makes an attempt are created to use the agriculture wastes like rice husk ash, palm nut shell and coconut shell saw mud, ground shell and feather palm shell as building materials within the past few decades in an exceedingly analysis study shows that the agriculture waste specifically feather palm shell used as coarse mixture satisfies the strength demand of structural lightweight weight concrete. In India, one among agricultural wastes coconut shell (CS), is made in abundance and has the potential to be used as coarse mixture in concrete. Utilization of CS as mixture to supply LWC could be a comparatively new field of application. This could be a vital achievement for society in our attempts towards maintainable improvements.
The bulk density of coconut shell is concerning five hundred and $600 \mathrm{~kg} / \mathrm{m}^{3}$ that make them light-weight weight. It's been found that coconut shell concrete simply attains the strength of quite seventeen MPa that is demand for structural lightweight weight concrete as per ASTM C330. the utilization of light weight concrete within the industry has gaining quality within the past few decades. Though there are several works done on the structural performance of lightweight concrete, these are largely confined to present aggregates, factory-made aggregates and aggregates from industrial by product. This experimental study aims to research the quality of coconut shell as complete replacement for coarse combination. The objectives and scope of present study are

a) To relate mechanical properties between control specimens and coconut shell specimens.

b) To provide economical construction material

\section{EXPERIMENTAL PROGRAM}

\subsection{Materials Descriptions}

\subsubsection{Cement}

The cement used for the present experimental investigation was ordinary Portland cement of 53 grade, conforming to IS: 12269-1987. The various characteristics of cement were tested as per the Indian Standards IS: 4031 - 1988. Specific Gravity of the cement was 3.15 . 
Table 1 Chemical Analysis for cement

\begin{tabular}{|l|l|}
\hline Composition & Test results \\
\hline $\mathrm{SiO}_{2}$ & 21.81 \\
\hline $\mathrm{Al}_{2} \mathrm{O}_{3}$ & 6.90 \\
\hline $\mathrm{Fe}_{2} \mathrm{O}_{3}$ & 3.71 \\
\hline $\mathrm{CaO}$ & 58.61 \\
\hline $\mathrm{Mgo}$ & 4.77 \\
\hline $\mathrm{K}_{2} \mathrm{O}$ & 0 \\
\hline $\mathrm{Na}_{2} \mathrm{O}$ & 0 \\
\hline $\mathrm{SO}_{3}$ & 0.40 \\
\hline $\mathrm{LOI}$ & 2.00 \\
\hline
\end{tabular}

\subsubsection{Silica Fume}

In this investigation, Silica fume was sourced from Astrra Chemicals, Chennai, Tamil Nadu was used in this investigation Specific gravity of silica fume was 2.12. Silica fume commonly used mineral admixtures which replace the cement by its fineness property. Silica fume is general passes through 75 microns and which is finer than cement.

Table 2 Chemical Analysis for Silica Fume

\begin{tabular}{|l|l|}
\hline Chemical composition & $\%$ \\
\hline $\mathrm{SiO}_{2}$ & 94.3 \\
\hline $\mathrm{Al}_{2} \mathrm{O}_{3}$ & 0.09 \\
\hline $\mathrm{Fe}_{2} \mathrm{O}_{3}$ & 0.10 \\
\hline $\mathrm{CaO}$ & 0.30 \\
\hline $\mathrm{Mgo}$ & 0.43 \\
\hline $\mathrm{K}_{2} \mathrm{O}$ & 0.83 \\
\hline
\end{tabular}

\subsubsection{Fine Aggregate}

Characteristic sand according to IS:383-1987 was utilized. Generally accessible River and having bulk density 1860 $\mathrm{kg} / \mathrm{m} 3$ was utilized the properties of fine aggregate are indicated in Table 3

Table 3 Properties of Fine Aggregate

\begin{tabular}{|l|l|l|}
\hline Sl.No & Property & Results \\
\hline 1 & Specific gravity & 2.56 \\
\hline 2 & $\begin{array}{l}\text { Fineness } \\
\text { modulus }\end{array}$ & 2.23 \\
\hline 3 & Grading zone & II \\
\hline
\end{tabular}

\subsubsection{Coconut Shells}

Large quantity of coconut shells is available in coconut oil mills. One tone of coconut shells were purchased from industries of coconut oils mills at Pollachi town the collected coconut shells were stacked in the SRM University campus and well seasoned manually by removing the fibers presented over the shells. The Coconut Shell aggregate were soaked for 24 hours in water and then taken from water, to allow dry under room temperature. The aggregate used were in saturated surface dry (SSD) condition throughout admixture to stop absorption happening throughout mixing. The coconut shells are pulverized a mini crusher developed in the Coconut Shell Concrete Research Center at SRM University. After crushing the coconut shell, they were sieved and the aggregate passing $12.5 \mathrm{~mm}$ sieve size was used in this investigation.

Table 4 Physical Properties of CS Aggregate

\begin{tabular}{|l|l|}
\hline Physical Properties & Coconut shell \\
\hline Specific gravity & 2.85 \\
\hline Bulk density (Loose) $\left(\mathrm{kg} / \mathrm{m}^{3}\right)$ & 470 \\
\hline Bulk density (compacted) $\left(\mathrm{kg} / \mathrm{m}^{3}\right)$ & 595 \\
\hline Fineness & 4.00 \\
\hline Bulk age $(\%)$ & 54 \\
\hline
\end{tabular}

Table 5 Chemical Properties of CS Aggregate

\begin{tabular}{|l|l|}
\hline Chemical properties & Coconut Shell \\
\hline Carbon $(\mathrm{C})(\%)$ & 49.80 \\
\hline Silica fume $(\mathrm{SiO} 2)(\%)$ & 64.20 \\
\hline Alumina $\left(\mathrm{Al}_{2} \mathrm{O}_{3}\right)(\%)$ & 6.51 \\
\hline Iron $\left(\mathrm{Fe}_{2} \mathrm{O}_{3}\right)(\%)$ & 6.98 \\
\hline Calcium $(\mathrm{CaO})(\%)$ & 10.56 \\
\hline $\begin{array}{l}\text { Sulphuric Anhydride }\left(\mathrm{SO}_{3}\right) \\
(\%)\end{array}$ & 1.05 \\
\hline Glucose $(\%)$ & 0.1 \\
\hline Fructose $(\%)$ & 0.1 \\
\hline Sucrose $(\%)$ & 0.1 \\
\hline
\end{tabular}

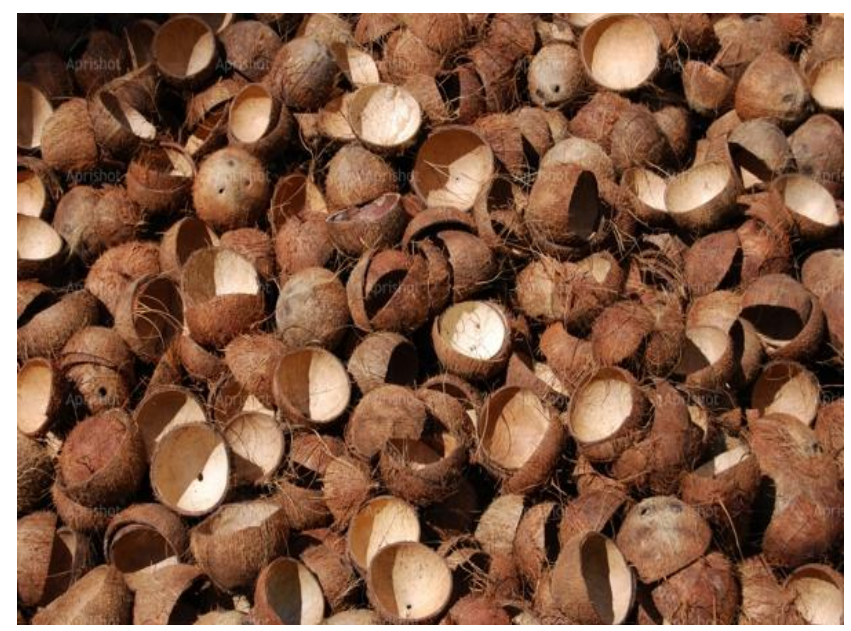

Fig 1: Collection of Coconut Shell 


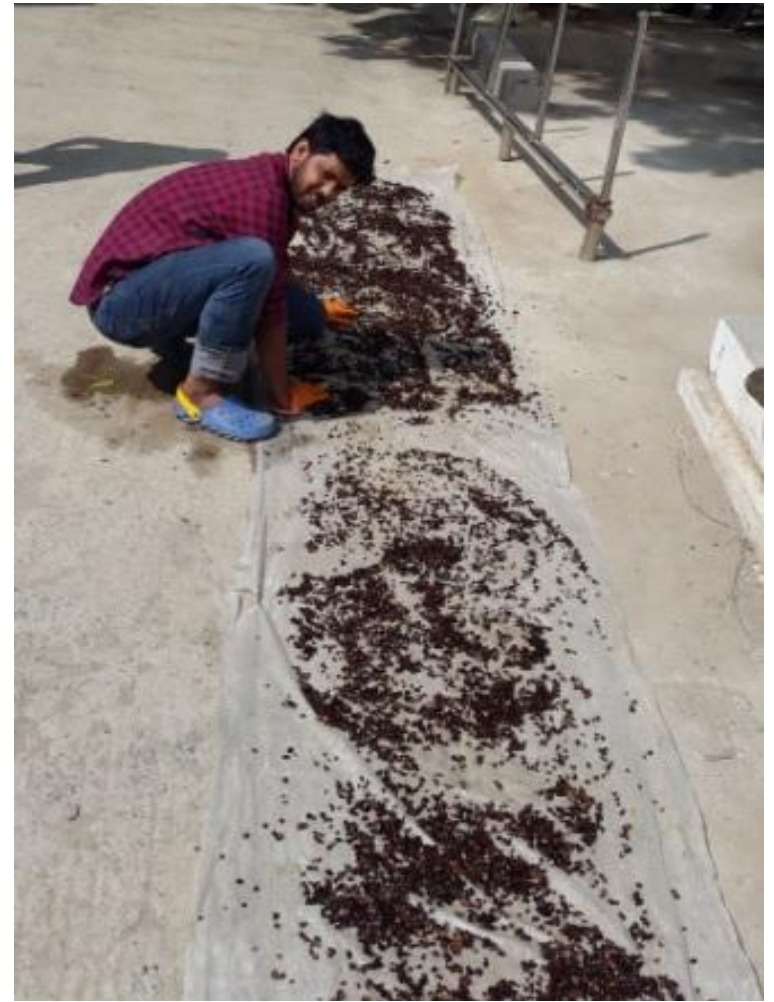

Fig 2: Coconut Shell Drying

\subsubsection{Water}

Portable tap water has been used for the concrete preparation and curing of specimen Water is an imperative element of cement as it effectively takes an interest in synthetic response with cement. Water conforming IS 4562000 was used, the water used in the preparation of motor should not necessary be distilled water, but must be free of all acids, bases and other distilled salts.

\subsection{Mix Proportion}

Mix design which are applied for conventional concrete cannot be used for light weight concrete due to deficiency of water absorption of aggregate, specific gravity of aggregate and moisture content.mix design are generally obtained from trail mixes.

Table 6 Mix Proportion

\begin{tabular}{|l|l|}
\hline MIX & $\begin{array}{l}\text { Replacement \% of Silica } \\
\text { Fume }\end{array}$ \\
\hline Mix 1 & OPC $100 \%$ \\
\hline Mix 2 & OPC 90\%+S.F $10 \%$ \\
\hline Mix 3 & OPC 85\%+S.F $15 \%$ \\
\hline Mix 4 & OPC $80 \%+$ S.F $20 \%$ \\
\hline Mix 5 & OPC 75\%+S.F 25\% \\
\hline Mix 6 & OPC 70\%+S.F 30\% \\
\hline
\end{tabular}

\subsection{Batching and Mixing}

For each combine, the specified quantities of the constituents were batched by weight. Concrete was mixed during a fifty metric weight unit capability drum sort mixer within the laboratory. Before staring mixer machine, the mixer drum was absolutely washed and allowed for couple of minutes to dry the drum. Coconut shell aggregates were initial placed and mixed with four-hundredth of the entire calculated water for one minute. Then the stream sand and half-hour of water is value-added with coconut shell coarse mixture. the blending was continued for 2 minutes. Finally the cement and also the remaining water were value-added and intermixture continued till the contemporary concrete becomes homogeneous.

\subsection{Casting and Curing}

All the specimens were cast in steel moulds. During collection of the mould to be used, the joints between the sections of mould were thinly coated with crude oil was applied between the contact surfaces of rock bottom of the mould and therefore the base plates as to confirm that no water escapes throughout filling of concrete

Test samples were made when practicable in the wake of mixing, thus as to convey full compaction of the concrete with neither detachment nor unnecessary laitance. Compaction was done by technique for an electric vibrating table .after top layer has been compacted; the surface of the concrete was done level with top of the mould using a trowel. They were de-moulded after 24 hours and cured in water at the room temperature of $25^{\circ}$

\subsection{Test Programme}

The cubes of $100 \times 100 \times 100 \mathrm{~mm}$ size and cylinders of 100 $\mathrm{mm}$ dia $\times 200 \mathrm{~mm}$ diameter were tested for Compression and Split Tensile. Tests were done as per following codes of Bureau of Indian Standards. The test for Compressive Strength and split strength on cubes were measured at 7 , 14and 28 days of curing as per IS: 516-1959.

\section{RESULTS AND DISCUSSIONS}

\subsection{Compressive Strength}

The results of compressive strength were conferred in table no 7. The test was carried out conforming to IS 516-1959 to get compressive strength at the age of seven, fourteen and twenty eight days. The cubes were tested exploitation Compression Testing (CTM) of capability $1500 \mathrm{kN}$. it had been found that the 28-day compressive strength of concrete varied within the vary of twenty. $17 \mathrm{~N} / \mathrm{mm}^{2}$ to twenty four. $13 \mathrm{~N} / \mathrm{mm}^{2}$. The most compressive strength is optimised at $25 \%$ replacement of silicon dioxide fume with cement. it's terminated that the concrete strength depends on the strength, stiffness and density of coarse aggregates. The compressive strength obtained for the cement content 510 $\mathrm{kg} / \mathrm{m} 3$ at seventh day, fourteenth day and twenty eighth day of the coconut shell concrete is suitable to be employed in the assembly of non-load support panels it needs the 
strength of $3.45 \mathrm{~N} / \mathrm{mm}^{2}$ at 28-day, ASTM C129-85. From the results, coconut shell combination shows some promise to be used in building construction. Within the perspective of this, coconut shell have to be compelled to be thought of as coarse total within the creation of light weight concrete for the auxiliary and non basic elements. It should, in any case, be seen that any analysis have to be compelled to be done before it may be used as building materials.

Table 7 Average Compressive Strength for Coconut Shell Concrete $\left(\mathrm{N} / \mathrm{mm}^{2}\right)$

\begin{tabular}{|l|l|l|l|l|}
\hline \multirow{2}{*}{ MIX } & \multicolumn{2}{|l|}{$\begin{array}{l}\text { Replacement } \\
\text { \% of Silica } \\
\text { Fume }\end{array}$} & \multicolumn{2}{|l|}{ Age of Curing } \\
\cline { 3 - 5 } & ${\mathbf{7}^{\text {th }}}^{\text {day }}$ & $\begin{array}{l}\mathbf{1 4}^{\text {th }} \\
\text { day }\end{array}$ & $\begin{array}{l}\mathbf{2 8}^{\text {th }} \\
\text { day }\end{array}$ \\
\hline NC & $\mathbf{0 \%}$ & 14.83 & 19.77 & 22.21 \\
\hline Mix 1 & $\mathbf{0 \%}$ & 11.61 & 16.52 & 20.17 \\
\hline Mix 2 & $\mathbf{1 0 \%}$ & 13.07 & 17.16 & 22.12 \\
\hline Mix 3 & $\mathbf{1 5 \%}$ & 14.79 & 19.91 & 23.12 \\
\hline Mix 4 & $\mathbf{2 0 \%}$ & 16.91 & 20.86 & 23.63 \\
\hline Mix 5 & $\mathbf{2 5 \%}$ & 17.64 & 21.45 & 24.13 \\
\hline Mix 6 & $\mathbf{3 0 \%}$ & 12.45 & 18.14 & 21.31 \\
\hline
\end{tabular}

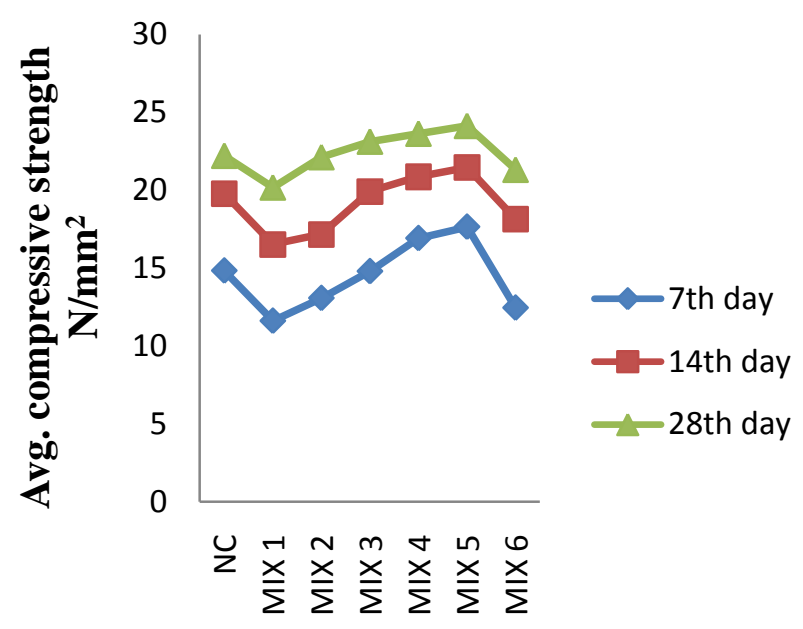

\section{PROPORTIONS}

Fig 3: Compressive Strength Graph for Coconut shell concrete

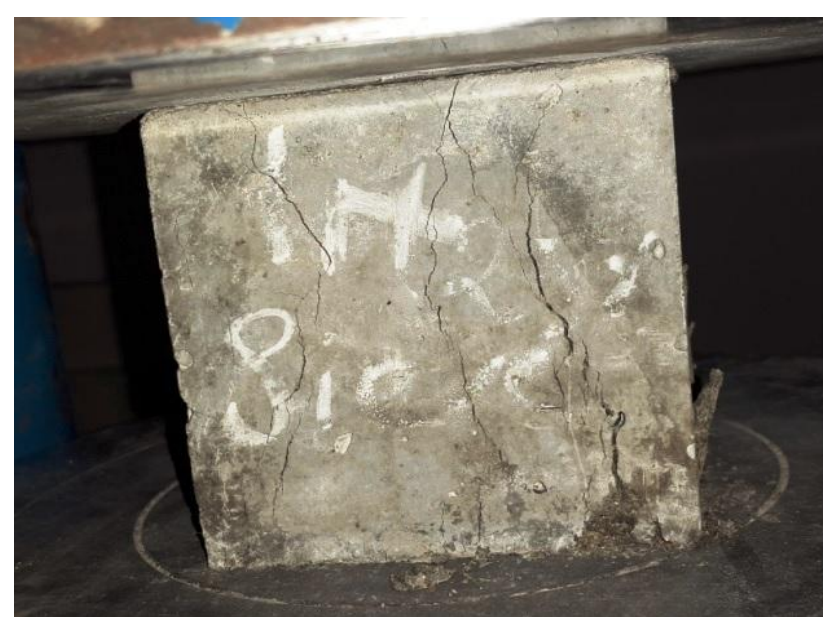

Fig 4 Tested CSC Cube

\subsection{Split Tensile Strength}

The results of split tensile strength were presented in table 8 . The optimum silica fume replacement $25 \%$ percentages for tensile strengths have been found to be a function of W/c ratio of the mix.

Table 8 Average Split tensile strength for Coconut Shell Concrete $\left(\mathrm{N} / \mathrm{mm}^{2}\right)$

\begin{tabular}{|l|l|l|l|l|}
\hline \multirow{2}{*}{ MIX } & \multirow{2}{*}{\begin{tabular}{l} 
Replacement $\begin{array}{l}|l| \\
\text { \%ge of Silica } \\
\text { Fume }\end{array}$ \\
\cline { 3 - 5 }
\end{tabular}} & $\begin{array}{l}\mathbf{7}^{\text {th }} \\
\text { day }\end{array}$ & $\begin{array}{l}\mathbf{1 4}^{\text {th }} \\
\text { day }\end{array}$ & $\begin{array}{l}\mathbf{2 8}^{\text {th }} \\
\text { day }\end{array}$ \\
\hline NC & $\mathbf{0 \%}$ & 1.223 & 1.797 & 2.587 \\
\hline Mix 1 & $\mathbf{0 \%}$ & 0.819 & 1.91 & 2.095 \\
\hline Mix 2 & $\mathbf{1 0 \%}$ & 0.946 & 1.297 & 2.256 \\
\hline Mix 3 & $\mathbf{1 5 \%}$ & 1.053 & 1.467 & 2.371 \\
\hline Mix 4 & $\mathbf{2 0 \%}$ & 1.095 & 1.191 & 2.393 \\
\hline Mix 5 & $\mathbf{2 5 \%}$ & 1.117 & 1.138 & 2.488 \\
\hline Mix 6 & $\mathbf{3 0 \%}$ & 0.787 & 1.063 & 2.180 \\
\hline
\end{tabular}

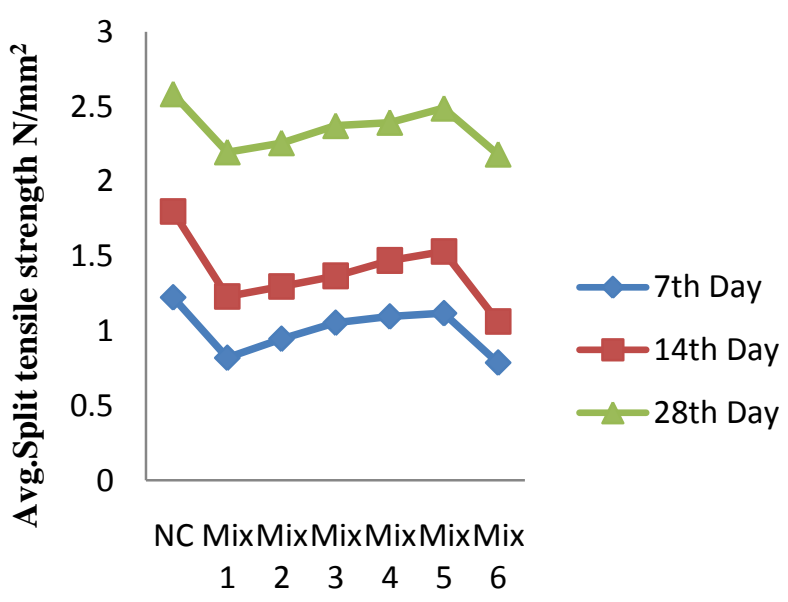

Mix proportions

Fig 5: Split Tensile Strength graph for Coconut shell concrete

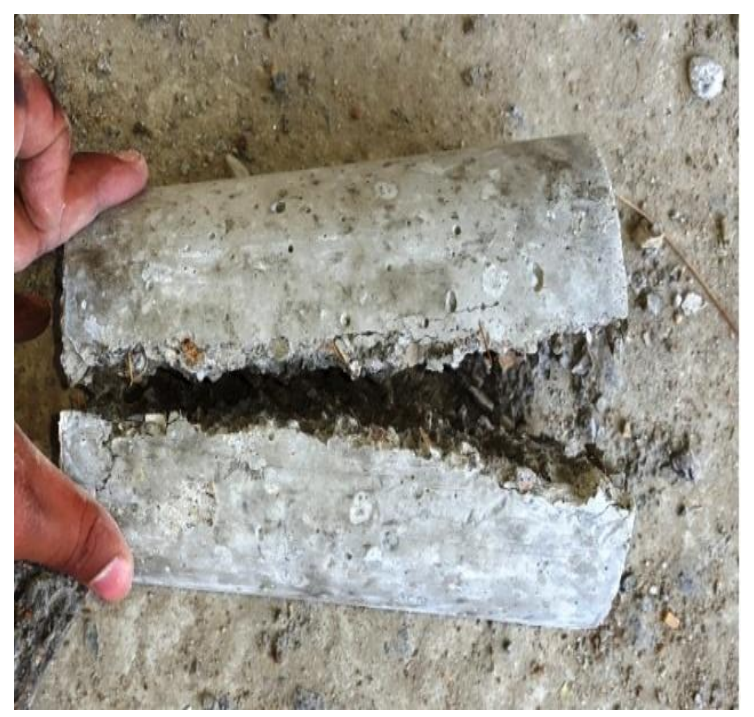

Fig 6: Tested CSC Cylinder 


\section{CONCLUSION}

This study presents the effective way of utilizing crushed coconut shell aggregate in concrete. Presently, coconut shell is available at low price in most tropical countries. Also the concrete obtained using coconut shell aggregates satisfy the minimum requirements of light weight concrete. Hence it is possible to made light weight concrete making use of coconut shells as an aggregate in concrete.

Based on the investigation, the following conclusions were made

- It was observed that the compressive strength of the light weight concrete using coconut shell aggregate increases with increasing age, but compressive strength decrease at $30 \%$ replacement of silica fume with cement.

- It was observed that split tensile strength decreases at, 30\% of replacement of Silica Fume with cement

- The compressive strength for Coconut Shell Concrete with replacement of $25 \%$ silica fume at $7^{\text {th }}, 14$ th and $28^{\text {th }}$ day varies in the range of 17.64 , 21.45 and $24.13 \mathrm{~N} / \mathrm{mm}^{2}$ respectively.

- The Split Tensile strength for Coconut Shell Concrete with replacement of $25 \%$ silica fume at $7^{\text {th }}, 14^{\text {th }}$ and $28^{\text {th }}$ day varies in the range of $1.117,1.138$ and $2.488 \mathrm{~N} / \mathrm{mm}^{2}$ respectively.

- The maximum compressive strength and split tensile strength is observed at $25 \%$ replacement of silica fume with cement.

- The light weight concrete design mix partial replacement with $25 \%$ of silica fume with cement has achieved compressive strength $24.13 \mathrm{~N} / \mathrm{mm}^{2}$ at $28^{\text {th }}$ day age with $98 \%$ compared to that of Normal concrete with several advantages over Normal concrete.

- The optimum $28^{\text {th }}$ day split tensile strength and compressive strength has been obtained in the range of 20-25\% silica fume replacement level.

\section{REFERENCES}

[1]. Abdulfatah Abubakar and Muhammed Saleh Abubakar Department of Civil Engineering Kaduna Polytechnic, Kaduna Volume 3, December 2011 on exploratory study of coconut shell as coarse aggregate in concrete.

[2]. Akshay S. Shelke, Kalyani R. Ninghot, Pooja P. Kunjekar, Shraddha P. Gaikwad Civil Engineering Department, Prof. Ram Meghe College of Engineering and Management, Amravati, Maharashtra, India. Volume 5, Number 3 (2014) Coconut Shell as partial replacement for coarse aggregate.

[3]. Amarnath Yerramala, Ramachandrudu Structures and Materials laboratory Department of Civil Engineering, Intell Engineering College, Anantapur, India Volume 1, Issue 6 (October2012) Properties of Concrete with Coconut Shells as Aggregate Replacement.

[4]. Daniel Yaw Osei Department of Civil Engineering Cape Coast Polytechnic, Cape Coast, Ghana. Volume 2 Issue 5 May. 2013 experimental assessment on coconut shells as aggregate in concrete.
[5]. J. Olumuyiwa Agunsoye, Talabi S. Isaac, Sanni O. Samuel Department of Metallurgical and Materials Engineering, University of Lagos, Lagos, Nigeria August 2012 study of mechanical behaviour of coconut shell reinforced polymer matrix composite

[6]. Vishwas P. Kukarni, Sanjay kumar B. Gaikwad Volume 2, Issue 12, June 2013 Comparative Study on Coconut Shell Aggregate with Conventional Concrete.

\section{BIOGRAPHY}

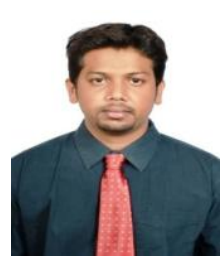

Shaik.Aliimran Tippu, Post Graduate Student, SRM University, Kattankulathur, chennai 